\title{
Assessment of Soil Erosion Risk in The Basin of Wadi Maged in Northern West Coast of Egypt Using Corine Model and Gis Techniques
}

\author{
Manal A. El-Nady ${ }^{1}$ and M. M. Shoman ${ }^{2}$ \\ ${ }^{1}$ Soil Science Department, Faculty of Agriculture, Cairo University, Giza and ${ }^{2} R S \&$ \\ GIS Unit, Soils, Water and Environment Research Institute, ARC., Egypt.
}

\begin{abstract}
COIL erosion is one of the major threats to the conservation of soil and water resources. The

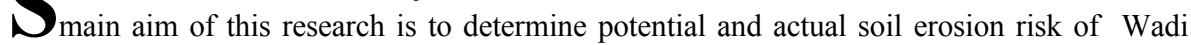
Maged basin using GIS techniques and COo Rdination of IN formation on the Environment (CORINE) model. The main factors of soil erosion including soil erodibility, erosivity, topography and vegetation cover were determined. Initially soil texture, soil depth, and surface stoniness maps were created and intersected in GIS environment in order to generate erodibility map. The Fournier precipitation and Bagnouls-Gaussen drought indices were determined based on meteorological data and erosivity was calculated. Potential erosion risk map was generated by composed soil erodibility, erosivity and slope layers. Results revealed that about 570.1 ha. of the study area was classified as no erosion risk. Areas under low and moderate potential soil erosion risk were about 8279.3 ha. and 10.0 ha. of the study area, respectively. The areas classified as high potential soil erosion risk was a small area $(0.2$ ha. $)$ in the north. Results of actual erosion risk revealed that actual erosion risk areas were less than the potential one (7044.2 ha.). These results confirm the role of land cover in protecting the soil surface from erosion. The assessment of soil erosion risk helps to prioritize critical areas for adopting suitable soil erosion prevention measures.
\end{abstract}

Keywords: CORINE model, Soil erosion risk, GIS, Wadi Maged basin, Egypt.

\section{Introduction}

Soil erosion is a serious problem throughout the world due to its adverse economic and ecoenvironmental impacts such as losses in land resources and decreases in land productivity, especially through nutrient rich sediment delivery that leads to eutrophication and reduces the overall storage capacity of reservoirs as well as life span (Eroglu et al., 2010). Reservoir siltation has direct negative economic and environmental consequences, since less water volume is available for water supply, irrigation and flood control. Managerial practices that minimize conditions of soil erosion can be effectively implemented if the intensity and spatial distribution of soil erosion are known. However, for a long time, it is difficult to assess soil erosion in a precise manner for the complex processes of soil erosion determined by multi-factor, natural and anthropogenic interactions (Lu et al., 2004 and Ananda \& Herath, 2003). Conventional erosion research methods, such as regular field experimentation or longterm monitoring, require substantial funding, time and manpower inputs. Thus accurate and timely assessment of soil erosion rate and spatial distribution for conservation planning is urgent in need. The Coordination of Information on the Environment (CORINE) model is an empirical model can predict soil erosion risk (SER) with spatial explicit (CORINE 1992). CORINE is a semi-qualitative cartographic method that involves designing and overlaying of several layers-thematic maps, and it can present the spatial heterogeneity of soil erosion risk (SER) within a GIS environment. It has a great advantage of simple structure and it is also easy to apply using GIS. The CORINE model correctly identified the areas of the Mediterranean, which have the highest 
risk of erosion (Gobin et al., 2003). CORINE model was widely applied by the European and Mediterranean countries for soil exion isk assessment (Husnjek et al, 2008. Parlak et al, 2007: Yuksel et al, 2008 and Aydin \& Tecimen, 2010). GIS technology is a powerful tool in environmental assessment through its advanee features for collecting storing maniputing, and displaying spatial data (Wang et al., 2003) RS technologies have been used to provide land cover information by using digital image processing techniques (Yuksel et al., 2008). Therefore, combination of RS, GIS, and CORINE mode provides the potential to assess soil erosion risk and its spatial distribution with reasonable costs and better accuracy in large areas. Objective of this study is to characterize the spatial distributio of soil erosion risk in Wadi Maged basin.

\section{Materials and Methods}

Study area

The study was conducted at Wadi Maged basin in the Northern Western part of Marsa Matrouh city and south of Zawyat Umm El-Rakham area as shown in Fig. 1. The study area covers an area of $88.6 \mathrm{~km} 2$ (about 8859.5 ha.) and located between longitudes $26^{\circ} 56^{\prime} 58.4^{\prime \prime}$ to $27^{\circ} 07^{\prime} 19.7^{\prime \prime}$ East and latitudes $31^{\circ} 11^{\prime} 10.1^{\prime \prime}$ to $31^{\circ} 22^{\prime} 33.5^{\prime \prime}$ North. The International Coastal road passes in the middle of the study area from east side to west side and $\mathrm{Al}$ Dabha Al-Sallum road pass through the south part

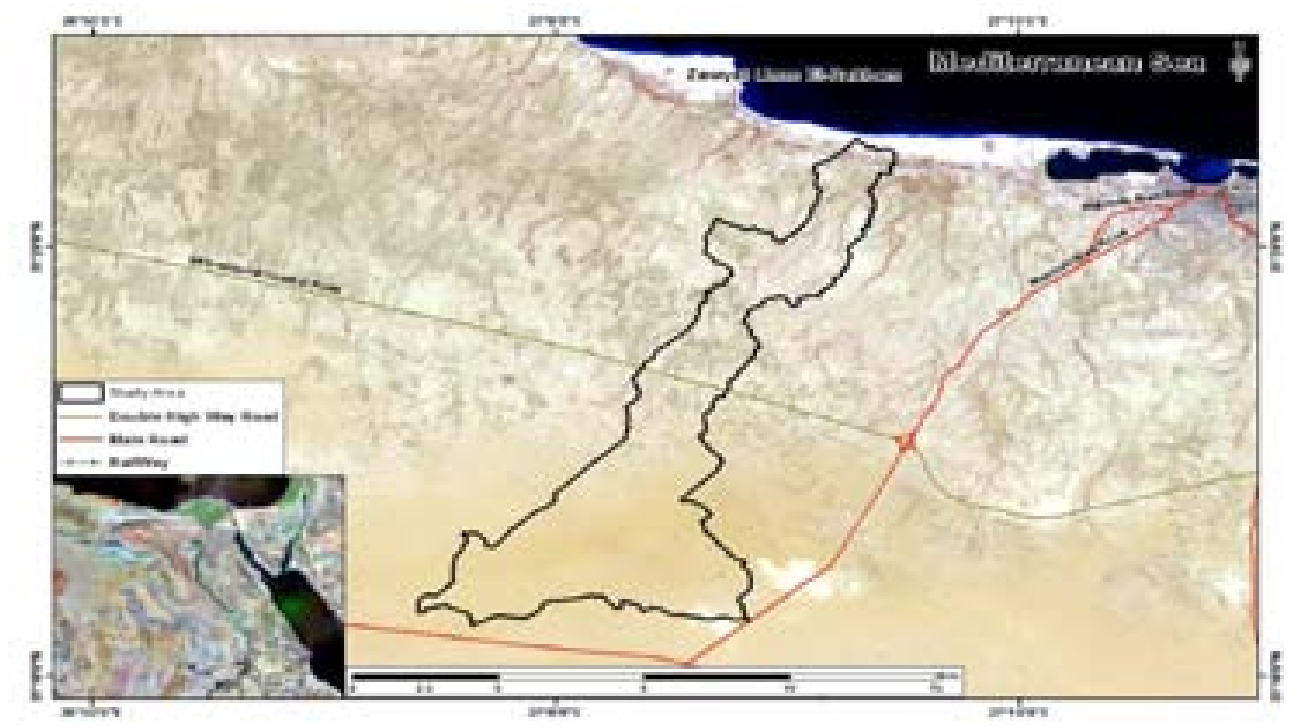

Fig. 1. Location map of the study area
Laboratory analyses

Laboratory analyses were carried out for rea contains number of close valleys started from Internth West costal road to the south up to the area is rainy in the winter, dry hot in the summer, where the minimum annual rain is $87.10 \mathrm{~mm}$ year and the maximum annul rain is $274.50 \mathrm{~mm} /$ year with an average rinfall of $145.06 \mathrm{~mm} / \mathrm{yen}$ of climatic period from 2002 up to 2014 (E.M.A. 2014)

\section{Materials and softwares}

Four topographic Maps, named; Wadi Maged, Kariat Ragwah, El Ramsa, and Abar Department of Military Survey, MSA (1986),

- LANDSAT-8 ETM+ of scene P179 R038 in 2015, projection: Universal Transverse Mercator (UTM), with Datum: WGS 1984 Ellipsoid parameters: $a=6378137.00$ and $1 /$ $=298.257$, Northern Hemisphere, and Zone 35.

(ERDAS imagine 2014, ArcGIS desktop V.10.3)

Field Work

Ten soil profiles were selected to define the soil types of these areas. Soil samples were collected based on the morphological description, and air-dried, gently crushed, and then sieved through a 2-mm sieve. Fractions below $2 \mathrm{~mm}$ were subjected to soil analyses.

Using field work, laboratory analysis particle size distribution, organic matter, calciun carbonate content, soil $\mathrm{pH}$ in the soil paste and electrical conductivity (EC) in the soil paste extract according to Klute, (1986) and Page et al., (1982)

Soil map creation combined with thematic map which created by visual interpretation of the satellite images, soil map of the studied area was generated to present soil properties (Zinck, 1988). In addition, to be as base map for the application of CORINE model.

CORINE model

The CORINE model is based on USLE (Universal Soil Loss Equation; Wischmeier, 1978) and developed by EC (European Communities) Geographical information systems (GIS) and CORINE model are used to detect soil erosion risk assessment and this play an important role in soil conservation planning.

An outline of the soil erosion model is shown in Fig. 2. As can be seen, assessments are carried out on a three point scale ranging from 1 (low) to 3 (high), with an additional class of 0 (no erosion) for areas (e.g. rock areas, settlement areas). As such, the model clearly represents a considerable simplification of the USLE. Results of using this technique provide sufficient discrimination to meet general policy needs. In particular, results allow the definition of areas of high erosion risk, where active measures to control soil erosion may be needed, and areas of low risk where agricultura practices probably present no threat.

Assessment of soil erosion risk is carried out in two steps. First, potential soil erosion risk is calculated by aggregating the indices of sol erodibility, rain erosivity and slope angle. This lead to indicate the inherent susceptibility of the land to erosion, irrespective of existing lan use. Second, actual soil erosion risk refers to the estimated present risk, taking into of current land use practice. This is calculated by including the vegetation cover index, to modify the estimated potential erosion risk.

The model thus involves the computation of four separate indices, which are then combined to get an assessment of erosion risk as follows :

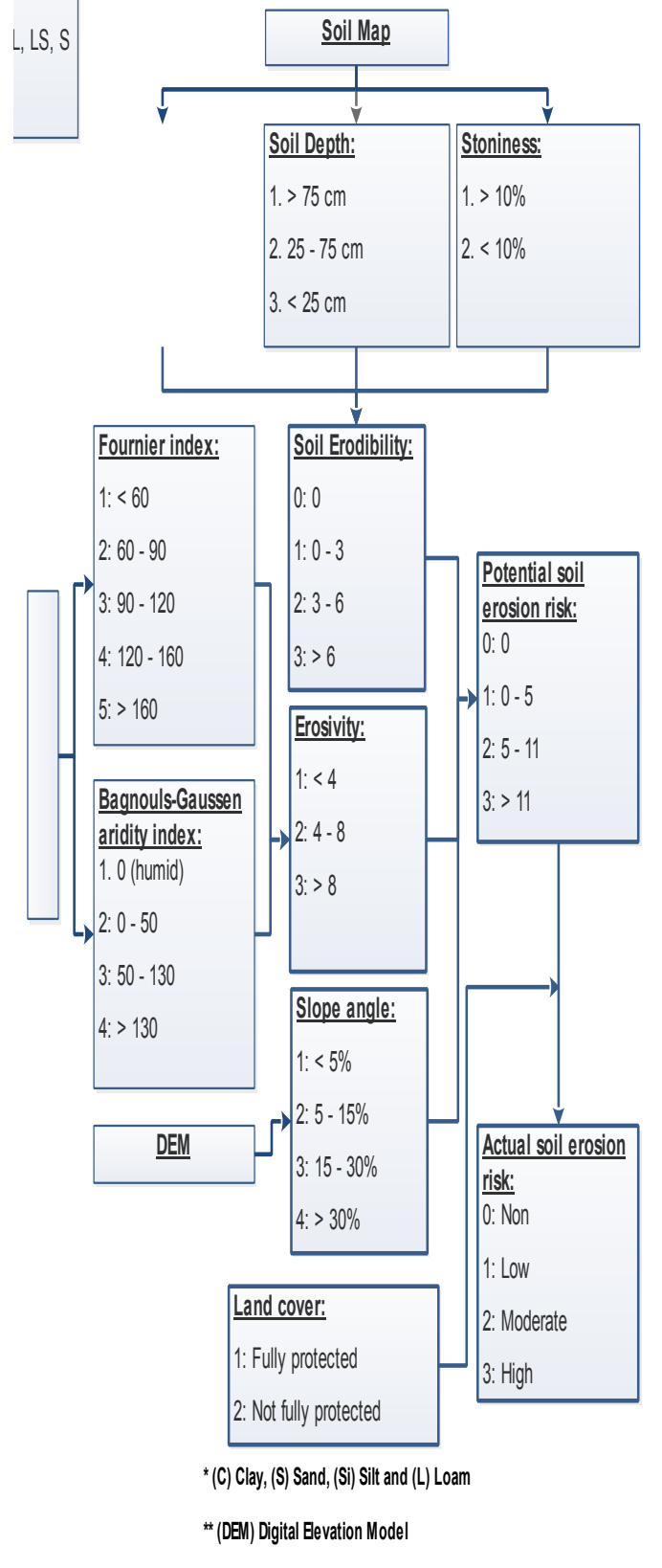

Fig. 2. Methodology for CORINE soil erosio assessment (CORINE, 1992)

Soil erodibility index

Soil erodibility refers to the susceptibility of the soil to erosion. Available data concerned the soil erodibility are texture, depth and th percentage of stones (Fig. 2 andTable 1). Table 1 showed that the texture data and soil dep were classified into three classes, while the soil stoniness refers to the percentage sufface cover of stones was classified as two classes

Egypt. J. Soil Sci., Vol. 57, №.1 (2017) 
TABLE 1. Classes and assigned weighing indices for the various parameters used for assessment of soil erodibility (CORINE model)

\begin{tabular}{clcc}
\hline \multicolumn{1}{c}{ Parameter } & \multicolumn{1}{c}{ Classes } & Index & Description \\
\hline \multirow{3}{*}{ Soil texture } & C, SC, SiC & 1 & Slightly erodible \\
& SCL, CL, SiCL, LS, S & 2 & Moderately erodible \\
& L, SiL, Si, SL & 3 & Highly erodible \\
\hline \multirow{3}{*}{ Soil Depth (cm) } & $>75$ & 1 & Slightly erodible \\
& 25 to 75 & 2 & Moderately erodible \\
& $<25$ & 3 & Highly erodible \\
\hline \multirow{2}{*}{ Stoniness (\%) } & $>10$ & 1 & Fully protected \\
& $<25$ & 2 & Not fully protected \\
\hline
\end{tabular}

Soil erodibility is calculated as the product of these three attributes, as follows (CORINE, 1992):

Soil erodibility index $=$ Soil Texture Index $X$ Soil Depth Index X Stones Index.

The soil erodibility index is then scaled as follows (Table 2):

TABLE 2. Erodibility classes of CORINe model

\begin{tabular}{ccc} 
Class & Description & Range \\
\hline 1 & Low & $>0$ to 3 \\
2 & Moderate & $>3$ to 6 \\
3 & High & $>6$
\end{tabular}
Asigned to areas (e.g. bare rock, settlement areas, water).

Rainfall erosion index (Erosivity Index) impact and also reflects the amount and rate of runoff likely to be associated with precipitation events. The rainfall and air temperature data were station of Marsa Matrouh as shown in Table 3:
A soil erodibility index of 0 (no erosion) is The erosivity quantifies the effect of rainfal collected from 2008 -2014 from Meteorologica

Erosivity is calculated by integrating two climatic indices including the modified Fournier index (FI) and Bagnouls-Gaussen aridity index (BGI) in CORINE model. Fournier index (FI) is computed according to the following equation, (Yuksel et al., 2008) :

$$
F I=\sum_{i=1}^{12} \frac{P^{i}}{P^{i}}
$$

where: $(\mathrm{Pi})$ is the total precipitation in month (i) in $(\mathrm{mm})$, and $(\mathrm{P})$ is the total annual precipitatio in $(\mathrm{mm})$.

The index of Bagnouls-Gaussen (BGI) is calculated according to the following equation, (Yuksel et al., 2008)

$$
B G I=\sum_{i=1}^{12}(2 t i-P i) K \bar{t}
$$

where : (ti) is the mean temperature for the month, $\left(\mathrm{P}_{1}\right)$ is the total precipitation for month, and $(\mathrm{K})$ represents the proportion of the month during which $(2 \mathrm{ti}-\mathrm{Pi})>0$.

Fournier index (FI) and index of BagnoulsGaussen (BGI) are classified as shown in (Table 4):

TABLE 3. Annual precipitation and average air temperature from 2008-2014

\begin{tabular}{|l|c|c|c|c|c|c|c|}
\hline \multicolumn{1}{|c|}{ Year } & $\mathbf{2 0 0 8}$ & $\mathbf{2 0 0 9}$ & $\mathbf{2 0 1 0}$ & $\mathbf{2 0 1 1}$ & $\mathbf{2 0 1 2}$ & $\mathbf{2 0 1 3}$ & $\mathbf{2 0 1 4}$ \\
\hline Precipitation & 192.9 & 121.6 & 131.1 & 209.0 & 167.8 & 130.4 & 137.4 \\
\hline Temperature & 22.13 & 21.81 & 22.92 & 21.84 & 22.26 & 20.62 & 20.94 \\
\hline
\end{tabular}

Egypt. J. Soil Sci., Vol. 57, №.1 (2017)
TABLE 4. The ranks of Fournier and Bagnouls-Gaussen indices

\begin{tabular}{|c|c|c|c|c|}
\hline Class & $\begin{array}{c}\text { FI } \\
\text { Range }\end{array}$ & $\begin{array}{c}\text { FI } \\
\text { Description }\end{array}$ & $\begin{array}{c}\text { BGI } \\
\text { Range }\end{array}$ & $\begin{array}{c}\text { BGI } \\
\text { Description }\end{array}$ \\
\hline 1 & $<60$ & Very low & 0 & Humid \\
\hline 2 & 60 to 90 & Low & $>0$ to 50 & Moist \\
\hline 3 & $>90$ to 120 & Moderate & $>50$ to 130 & Dry \\
\hline 4 & $>120$ to 160 & High & $>130$ & Very dry \\
\hline 5 & $>160$ & Very high & & \\
\hline
\end{tabular}

Finally, erosivity index is determined by combining these two climatic indices as follows : Erosivity index = FI X BGI

PSER $=$ soil erodibility index $X$ Erosivity index $X$ slope index

Erosivity index is classified as shown in (Table 5):

This is classified into an erosion scale, ranging
from 0 (no potential soil erosion risk - bare rock)

TABLE 5. Erosivity classes of Corine model

\begin{tabular}{ccc} 
Class & Description & Range \\
\hline 1 & Low & $<4$ \\
2 & Moderate & 4 to 8 \\
3 & High & $>8$ \\
\hline
\end{tabular}

Slop index

Slope layer was derived from the digital elevation model (DEM), and classified according to CORINE model to four classes depending on slope angle percentage as in the Table 6 .

\section{TABLE 6. Classes of slope percentage by CORINE} model

\begin{tabular}{|c|c|c|}
\hline Class & Slope Angle (\%) & Classification \\
\hline 1 & $<5$ & Gentle to flat \\
\hline 2 & 5 to15 & Gentle \\
\hline 3 & $>15$ to 30 & Step \\
\hline 4 & $>30$ & Very steep \\
\hline
\end{tabular}

Land cover index

Land cover classes were obtained by classification process on satellite images of the studied area, and represented the different types of ground cover. According to CORINE model, and cover index was classified by the degree of protection of the soil into two classes: (1) fully protected, which includes forsts, bodics of waty construction, roads and rocky Land. (2) Not fully protected which includes land crops and fruit trees.

Potential soil erosion risk (PSER): As indicated in Fig. 1, the potential soil erosion index (PSER) is calculated as : to 3 (high erosion risk). This index influences by coll properties and climate and does not take into etsion; it the potential protective role of vegcenario and can be interpeted as the resion risk assuming the absence of any protective measures.

Actual soil erosion risk (ASER)

Actual soil erosion risk index is derived by modifying the estimated potential soil erosion risk

\begin{tabular}{|c|c|c|c|c|c|}
\hline $\begin{array}{l}\begin{array}{c}\text { Potential } \\
\text { soil }\end{array} \\
\text { soil }\end{array}$ & & Non & Low & Moderate & High \\
\hline $\begin{array}{l}\text { erosion } \\
\text { risk index }\end{array}$ & & 0 & 1 & 2 & 3 \\
\hline Lan & 1 & 0 & 1 & 1 & 2 \\
\hline $\begin{array}{l}\text { inder } \\
\text { inder }\end{array}$ & 2 & 0 & 1 & 2 & \\
\hline
\end{tabular}
index according to the vegetation cover as follows

\section{$\underline{\text { Results and Discussion }}$}

isual interpretation

$\checkmark$ isual interpretation was done on false colo composite of bands 5, 4, 3 of Landsat-8 scale $1: 50,000$ to produce a base map for the fied work activities and other purposes related to the present study. The visual analysis was based on the physiographic analysis methods according to Zinck (1988).

Digital elevation model (DEM)

DEM was created using geostatistical at a two-steps procedure: (a) Calculations of the

Egypt. J. Soil Sci., Vol. 57, №.1 (2017) analysis. Geostatistical analysis was carried ou 
experimental semi-variogram and fitting a model. (b) Interpolation through ordinary Kriging, which uses the seni-variogram parameters (Stein, 1998) From the semi-variogram opertion, it could be possible to define which opectation, the experimental semi-variogram values. By calculating the goodness of fit and select of By fitted model, the model parameters of Kriging method could be applied

The estimated or predicted values are thus a linear combination of the input values, (Stein, 1998). Kriging can be seen as an interpolation

was used as the main technique for geostatistical (D) (DEM) as shown in Fig. 3

Defining the soil classes of the studied area

Based on the classes of digital elevation model of the studies area, soil samples were collected from 10 soil profiles based on the morphological description. Results in Table 7 showed that, the gravels percentage ranged from 15 to $55 \%$. The valley.

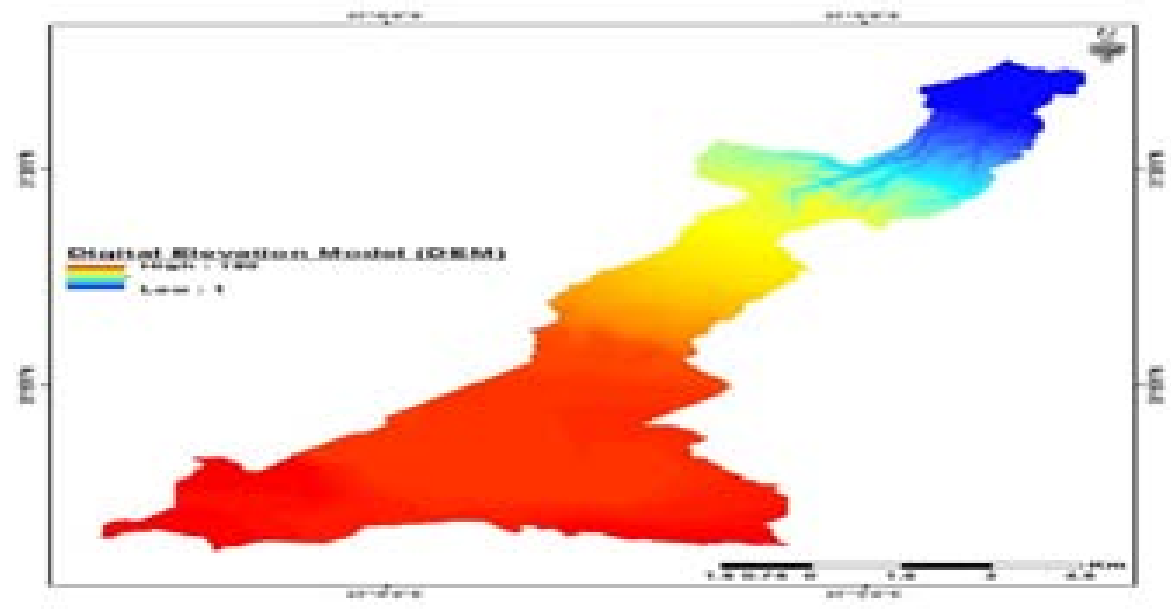

Fig. 3. Digital Elevation Model (DEM) map of the studied area.

The soils of this area have deep effective soil depth $(100-120 \mathrm{~cm})$ in the coarse valley and shallow to moderate deep effective soil depth $(50-90 \mathrm{~cm})$ out the coarse valley. The EC values ranged from $4.3 \mathrm{dS} / \mathrm{m}$ up to $7.6 \mathrm{dS} / \mathrm{m}$ wit an average of $5.3 \mathrm{dS} / \mathrm{m}$, therefore, this soil is moderately saline soils and the dominant salt is sodium chloride. The $\mathrm{pH}$ values ranged from 7.6 to 8.7 with an average of 8.3 . The total content of calcium carbonate percentage ranged from 24.8 up to $37.1 \%$ with an average of $33.6 \%$. These soils are moderately to strongly calcareous soils. The gypsum content percentage was low and ranged from 0.14 to $1.3 \%$ with an average of $0.35 \%$. These soils classified as non-gypsiric soils. The organic matter percentage was very low and ranged from 0.06 to $0.24 \%$ with an average of $0.12 \%$. The ground water depth is more than 150 $\mathrm{cm}$, therefore, these soils were classified as very deep ground water.

Egypt. J. Soil Sci,, Vol. 57, No.1 (2017)

According to the results of physical and chemical properties of the soil samples, soils of Wadi Maged basin was classified as shown in Fig. 4. and Table 8.

According to the results shown in Fig. 4 an Table 7, it was found that Typic Torripsamments was the dominant class in Wadi Maged basin where occupied an area of about 6309.7 ha. $(71.2 \%$ of total area) and was represented by soil profiles 8,9 and 10 , while the minimum class of the basin was Lithic Torripsamments where occupied an area of about 492.7 ha. (5.5\% of total area) and was areas occupied an area of about 570 ha. $(6.4 \%$ of total area) (Table 8). dominant soil textures are sandy loam and loamy

TABLE 7. Physical and chemical properties of the studied soil profiles of Wadi Maged basin

\begin{tabular}{|c|c|c|c|c|c|c|c|c|c|c|}
\hline Profile & $\begin{array}{l}\text { Depth } \\
(\mathrm{cm})\end{array}$ & pH & $\begin{array}{c}\text { Gravels } \\
\%\end{array}$ & $\begin{array}{c}\text { EC } \\
(\mathrm{d} / \mathbf{m})\end{array}$ & $\begin{array}{l}\text { Total Sand } \\
\text { (\%) }\end{array}$ & $\begin{array}{l}\text { Silt } \\
(\%)\end{array}$ & $\begin{array}{l}\text { Clay } \\
(\%)\end{array}$ & Texture & $\begin{array}{l}\text { OM } \\
(\%)\end{array}$ & $\begin{array}{c}\mathrm{CaCO}_{3} \\
(\%)\end{array}$ \\
\hline \multirow{4}{*}{ P1 } & $0-20$ & 8.5 & 35 & 7.3 & 63.3 & 21.4 & 15.3 & $\begin{array}{l}\text { Sandy Loam } \\
\end{array}$ & 0.24 & 35.9 \\
\hline & $20-45$ & 8.4 & 30 & 7.6 & 65.0 & 22.9 & 12.1 & Sandy Loam & 0.21 & 37.1 \\
\hline & $45-70$ & 8.6 & 30 & 6.5 & 70.4 & 23.7 & 5.9 & Sandy Loam & 0.13 & 33.5 \\
\hline & $70-120$ & 8.5 & 55 & 5.5 & 75.7 & 19.9 & 4.4 & Loamy Sand & 0.10 & 33.8 \\
\hline \multirow{4}{*}{ P2 } & $0-35$ & 8.5 & 35 & 5.3 & 68.6 & 17.9 & 13.5 & Sandy Loam & 0.22 & 35.9 \\
\hline & $35-65$ & 8.4 & 45 & 5.5 & 68.9 & 19.3 & 11.8 & Sandy Loam & 0.13 & 35.7 \\
\hline & $\begin{array}{ll}65-80 \\
\end{array}$ & 8.6 & 45 & 4.8 & 76.9 & 18.5 & 9.6 & Sandy Loam & 0.11 & 33.1 \\
\hline & $80-120$ & 8.1 & 45 & 5.4 & 77.7 & 18.7 & 3.6 & Loamy Sand & 0.09 & 34.0 \\
\hline \multirow{4}{*}{ P3 } & $0-25$ & 8.4 & 40 & 5.1 & 68.4 & 18.5 & 13.1 & Sandy Loam & 0.23 & 36.1 \\
\hline & $25-50$ & 8.6 & 45 & 5.7 & 69.5 & 18.8 & 11.7 & Sandy Loam & 0.20 & 35.3 \\
\hline & $50-80$ & 8.5 & 35 & 5.8 & 76.3 & 19.1 & 4.6 & Loamy Sand & 0.11 & 33.4 \\
\hline & $80-120$ & 8.4 & 25 & 5.5 & 77.4 & 18.6 & 4.0 & Loamy Sand & 0.08 & 34.9 \\
\hline \multirow{3}{*}{ P4 } & $0-30$ & 8.5 & 25 & 6.1 & 72.1 & 16.4 & 11.5 & Sandy Loam & 0.17 & 36.3 \\
\hline & $30-65$ & 8.7 & 30 & 5.9 & 72.6 & 16.7 & 10.7 & Sandy Loam & 0.11 & 30.5 \\
\hline & $65-120$ & 8.3 & 20 & 5.6 & 78.4 & 18.3 & 3.3 & Loamy Sand & 0.10 & 34.7 \\
\hline \multirow{3}{*}{ P5 } & $0-35$ & 8.2 & 15 & 5.3 & 75.9 & 15.5 & 8.6 & Sandy Loam & 0.13 & 35.5 \\
\hline & $35-65$ & 8.3 & 15 & 5.9 & 77.9 & 14.8 & 7.3 & Loamy Sand & 0.11 & 33.3 \\
\hline & $65-100$ & 8.1 & 10 & 5.0 & 79.6 & 17.3 & 3.5 & Loamy Sand & 0.10 & 34.9 \\
\hline \multirow{3}{*}{ P6 } & $0-40$ & 8.1 & 33 & 4.8 & 80.1 & 13.8 & 6.1 & Loamy Sand & 0.13 & 34.7 \\
\hline & $40-70$ & 8.3 & 41 & 4.5 & 80.9 & 15.6 & 3.5 & Loamy Sand & 0.09 & 33.5 \\
\hline & $70-100$ & 8 & 30 & 4.9 & 79.3 & 17.0 & 3.7 & Loamy Sand & 0.10 & 35.0 \\
\hline \multirow{2}{*}{ P7 } & $0-15$ & 7.6 & 35 & 4.3 & 92.0 & 6.3 & 1.7 & Sandy & 0.09 & 24.9 \\
\hline & $15-45$ & 7.9 & 40 & 4.5 & 91.0 & 7.5 & 1.5 & Sandy & 0.06 & 36.0 \\
\hline \multirow{2}{*}{ P8 } & $0-40$ & 7.8 & 20 & 4.3 & 83.0 & 11.1 & 5.9 & Loamy Sand & 0.11 & 35.6 \\
\hline & $40-100$ & 7.9 & 15 & 4.9 & 83.1 & 13.4 & 3.5 & Loamy Sand & 0.08 & 33.5 \\
\hline \multirow{3}{*}{ P9 } & $0-20$ & 8.4 & 33 & 4.6 & 89.1 & 8.0 & 3.5 & Sandy & 0.10 & 24.8 \\
\hline & $20-50$ & 8.5 & 35 & 4.3 & 90.2 & 7.3 & 2.5 & Sandy & 0.10 & 28.5 \\
\hline & $50-90$ & 8.5 & 25 & 4.9 & 89.7 & 7.5 & 2.8 & Sandy & 0.08 & 32.7 \\
\hline \multirow{3}{*}{ P10 } & $0-25$ & 8.7 & 30 & 5.0 & 88.3 & 7.9 & 3.8 & Sandy & 0.11 & 35.8 \\
\hline & $25-55$ & 8.6 & 25 & 4.3 & 88.7 & 8.3 & 3.0 & Sandy & 0.08 & 31.0 \\
\hline & $\begin{array}{l}55-90 \\
\end{array}$ & 8.3 & 15 & 4.4 & 90.6 & 7.1 & 2.3 & Sandy & 0.06 & 30.7 \\
\hline
\end{tabular}
represented by soil profile No. 7. Also present rock

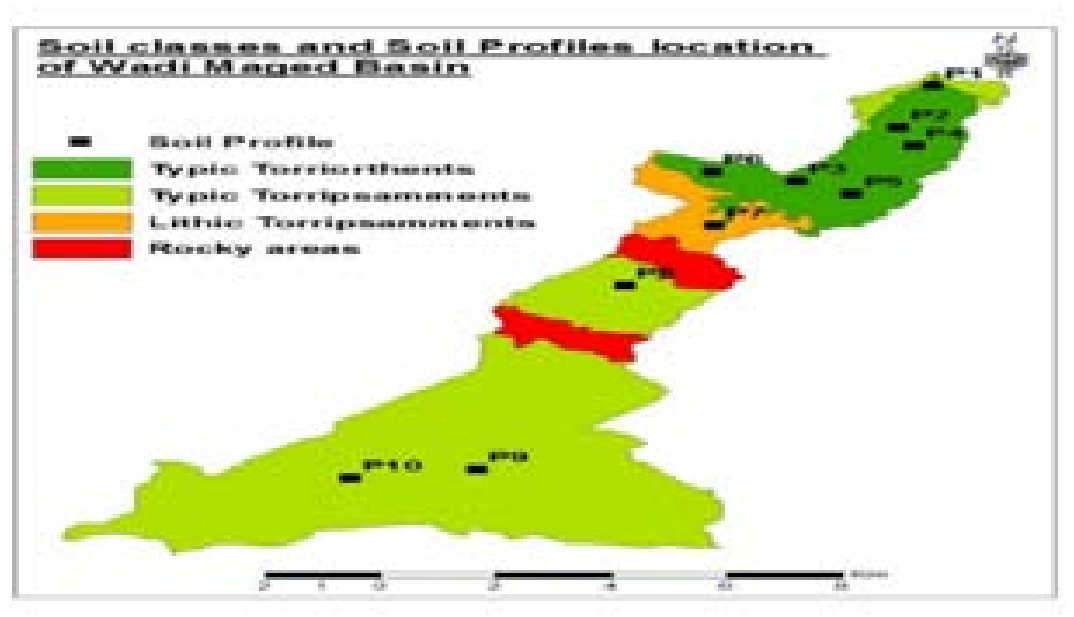

Fig. 4. Soils classes and soil profiles location of Wadi Maged basin

Egypt. J. Soil Sci., Vol. 57, No.1 (2017) 


\section{TABLE 8. Soil classifications units of Wadi Maged basin}

\begin{tabular}{|c|c|c|c|c|}
\hline \multirow{2}{*}{ Taxonomy units } & $\begin{array}{c}\text { Representative soil } \\
\text { profiles No. }\end{array}$ & \multicolumn{3}{|c|}{ Area } \\
\cline { 2 - 5 } & & Fed. & ha. & $\%$ \\
\hline Typic Torriorthents & $1,2,3,4,5,6$ & 3540 & 1486.8 & 16.8 \\
\hline Typic Torripsamments & $8,9,10$ & 15023 & 6309.7 & 71.2 \\
\hline Lithic Torripsamments & 7 & 1173 & 492.7 & 5.6 \\
\hline Rocky areas & -- & 1358 & 570.4 & 6.4 \\
\hline Total & \multicolumn{4}{|l}{} \\
\hline \multicolumn{2}{|r|}{} & 21094 & 8859.5 & 100.0 \\
\hline
\end{tabular}

CORINE model and Remote sensing and GIS integration

The CORINE model was used in integration with remote sensing and Geographic informatio system (GIS) techniques to produce soil erodibility, erosivity, slope angle and surface cover maps as essential database for evaluating actual and potential erosion risk.

\section{Soil erodibility}

In terms of soil texture, silty, very fine sand, and clay soils tend to be less erodible than sand, sandy loam, and loamy soils (CORINE, 1992). The les erodible soils are regarded as being of inherently low erodibility due to their high cohesiveness. In

contrast, the highly erodible soils are typically lack cohesiveness and have low structural stability whilst still permitting significant overland flow. Texture of Wadi Maged basin was classified shown in Fig. 5 and Table 9.

Results in Fig. 5. and Table 9. recorded that About 6630.9 ha (about $74.8 \%$ of the studied
area) are moderate erodible (texture index $=2$ ) which characterized as a soil medium resistance to erosion (Corbane et al.,2008), where texture classes are sandy and loamy sand. While about 1658.3 ha (about $18.7 \%$ of the studied area) are high erodible (texture index $=3$ ) which characterized as a high soils resistance to erosion, where texture class is sandy loam.

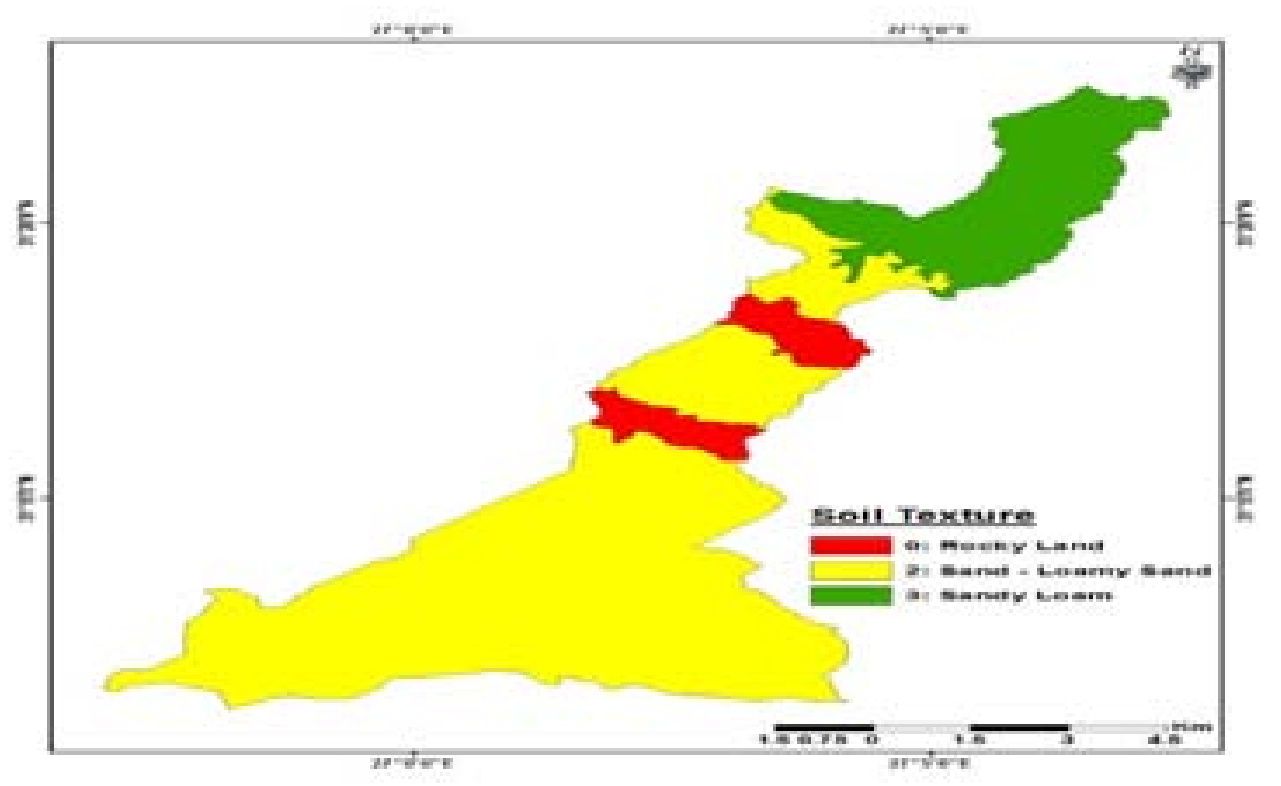

Fig. 5. Soil texture map of the study area

Egypt. J. Soil Sci, Vol. 57, No.1 (2017)

TABLE 9. Soil texture classes of the study area

\begin{tabular}{|c|c|c|c|}
\hline Texture Class & Area (ha) & Area (fed) & \% \\
\hline ( (No erodible) & 570.3 & 1357.9 & 6.4 \\
\hline 2 (Moderate erodible) & 6630.9 & 15787.8 & 74.8 \\
\hline 3 (Highly erodible) & 1658.3 & 3948.3 & 18.7 \\
\hline Total Area & $\mathbf{8 8 5 9 . 5}$ & $\mathbf{2 1 0 9 4 . 0}$ & $\mathbf{1 0 0 . 0}$ \\
\hline
\end{tabular}

Soil depth:

Soil depth is assumed an important factor in soil crodibility for two reasons. Firstly, dep sils typically absorb and hold larger voly, dee water than shallow soils, and thereby generate overland flow less readily. Secondly, soil los tends to be less damaging in deep soils because of their greater tolerance to erosion. Results in Fig. 6 and Table 10 recorded that, about 7796.3 ha (about $88.0 \%$ of the studied area) have dept $>75 \mathrm{~cm}$ (low susceptibility to erosion). This are

has higher water holding capacity, and thus is able to absorb larger rainfall amounts before overland flow is generated. About 496.1 ha ( $5.6 \%$ of the studied area) have depth $25-75 \mathrm{~cm}$ (medium susceptibility to erosion) and 567.0 ha about $6.4 \%$ of the studied area) have depth $<5$ $\mathrm{cm}$ (severe soil erosion susceptibility). Erosion of deep soils is considered less problematic because of their greater tolerance to erosion (CORINE, 1992).

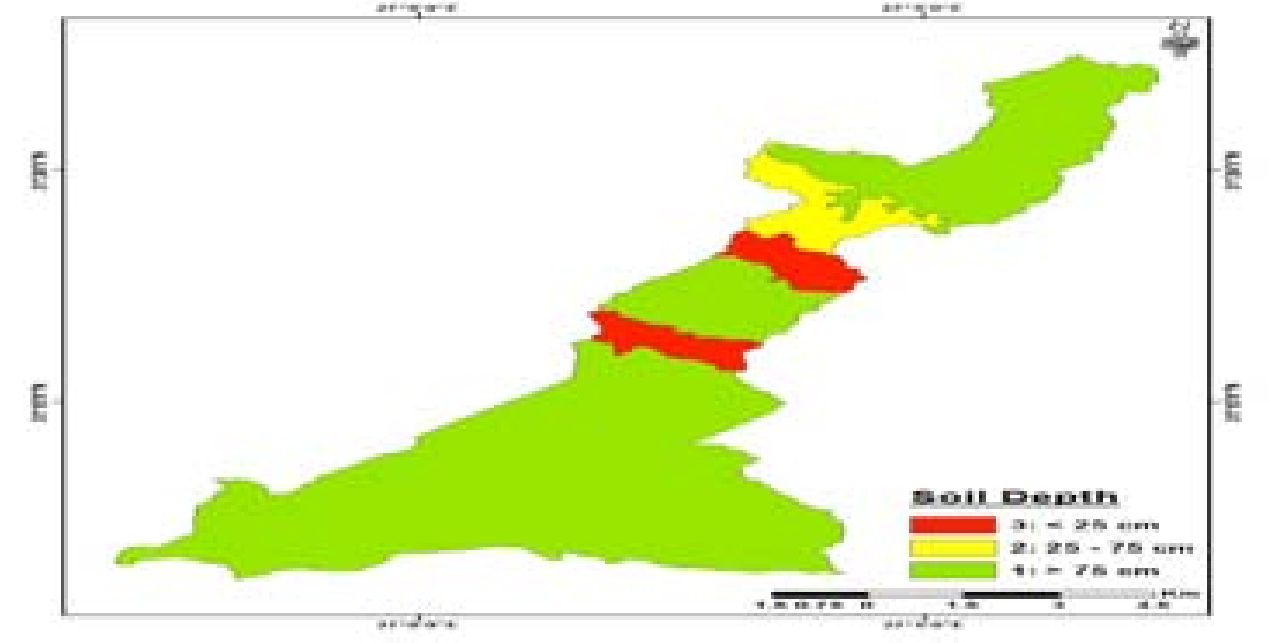

Fig. 6. Soil depth map of the study area

TABLE 10. Depth classes of the study area

\begin{tabular}{|c|c|c|c|}
\hline Depth Class & Area (ha) & Area (fed) & \% \\
\hline 1 & 7796.3 & 18562.7 & 88.0 \\
\hline 2 & 496.1 & 1181.3 & 5.6 \\
\hline 3 & 567.0 & 1350.0 & 6.4 \\
\hline Total Area & $\mathbf{8 8 5 9 . 5}$ & $\mathbf{2 1 0 9 4 . 0}$ & $\mathbf{1 0 0 . 0}$ \\
\hline
\end{tabular}

c. Stoniness: revealed that a percentage of stones of soil profiles

were more than $10 \%$. These soils with coverage of more than $10 \%$ are providing full protection of the soil. However, Yuksel et al. (2008) reported Egypt. J. Soil Sci., Vol. 57, No.1 (2017) 
that surface cover of stones may protect the soil from rain splash but after surface runoff is initiated, existence of stones might cause adverse effects by encouraging rill erosion through water turbulences.

Soil erodibility index:

Soil erodibility refers to the susceptibility of the soil to erosion. General level, this depend primarily on its resistance to particle detachment by rain splash or runoff and on its ability to absorb rainfall. The erodibility index was calculated and classified as shown in Fig. 7. Soil erodility

classified into no erosion, low and moderate erosion. The distribution of the areas with soil erodibility classes is given in Table 11

Results indicated that 7796.3 ha (about $88.0 \%$ of the studied area) have low erodibility and 496.1 ha (about $5.6 \%$ of the studied area) have moderate erodibility. It is noticed that the of $25-75 \mathrm{~cm}$. Results also showed with soil depth studied area is located within the first class, of the the value of the index indicated susceptibility of soil to no erosion.

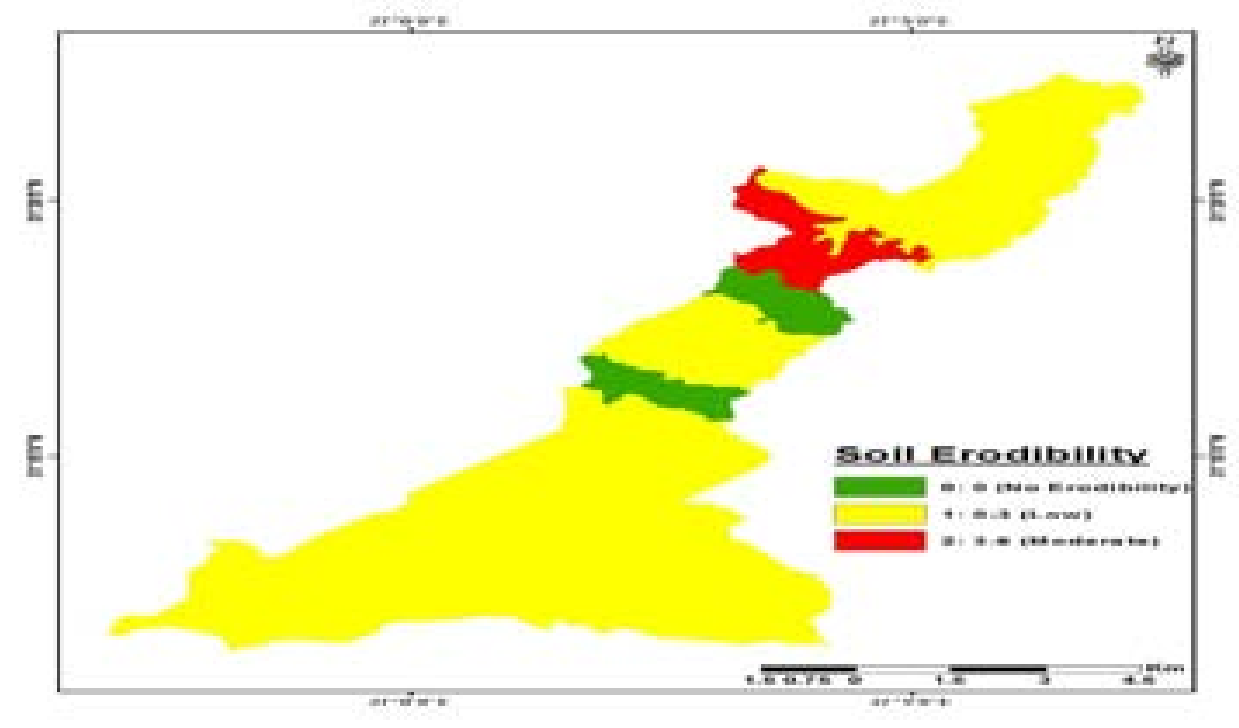

Fig. 7. Soil erodibility map of the study area

TABLE 11. Soil erodibility classes of the study area

\begin{tabular}{|c|c|c|c|}
\hline Soil erodibility class & Area (ha) & Area (fed) & \% \\
\hline 0 & 567.0 & 1350.0 & 6.4 \\
\hline 1 & 7796.3 & 18562.7 & 88.0 \\
\hline 2 & 496.1 & 1181.3 & 5.6 \\
\hline Total Area & $\mathbf{8 8 5 9 . 5}$ & $\mathbf{2 1 0 9 4 . 0}$ & $\mathbf{1 0 0 . 0}$ \\
\hline
\end{tabular}

Erosivity index (EI)

The erosivity quantifies the effect of rainfal impact and also reflects the amount and rate of runoff likely to be associated with precipitation events. Meteorological data were used to calculat the erosivity index for the study area as shown in Table 12.

Results showed that Fournier index values anged from 18.10 to 50.11 with a mean value of 31.62 which located within the first class. Values of the Bagnouls-Gaussen index ranged between 41.08 to 112.51 with a mean value of 66.27 located within the three class according to CORINE model. The erosivity index value of the whole studied area is equal to 3 which is within the class one that indicates low rainfall erosion index. This study indicated that environmental system is generally influenced by small changes in climate.

TABLE 12. Rainfall erosivity index, Forner and Bagnouls-Gaussen indices for the year

\begin{tabular}{|c|c|c|}
\hline \multirow{2}{*}{ Year } & \multicolumn{2}{|c|}{ Index } \\
\cline { 2 - 3 } & $\mathbf{( F I )}$ & $\mathbf{( B G I )}$ \\
\hline 2008 & 50.11 & 112.51 \\
\hline 2009 & 18.10 & 43.57 \\
\hline 2010 & 30.36 & 53.78 \\
\hline 2011 & 35.85 & 74.40 \\
\hline 2012 & 32.25 & 73.87 \\
\hline 2013 & 32.51 & 64.71 \\
\hline 2014 & 22.19 & 41.08 \\
\hline average & $\mathbf{3 1 . 6 2}$ & $\mathbf{6 6 . 2 7}$ \\
\hline Class & $\mathbf{1}$ & $\mathbf{3}$ \\
\hline
\end{tabular}

Slope degree

Slope is an important factor influencing overland flow generation and has an importan influence on controlling erosion rates due to its effect on the rate of runoff and the amount of water infiltration in the soil (Dragut and Eisank, 2012). Erosion only occurs when slope exceeds a critical angle and it increases with the absence of vegetation cover. Moreover, it has also significan effect on the net rain excess, the flow velocity, and shear stress (Liu et al., 2001). According to CORINE (1992), slope degrees were categorized into four sub-slope groups, these slope groups are presented in Fig. 7. and Table 13.

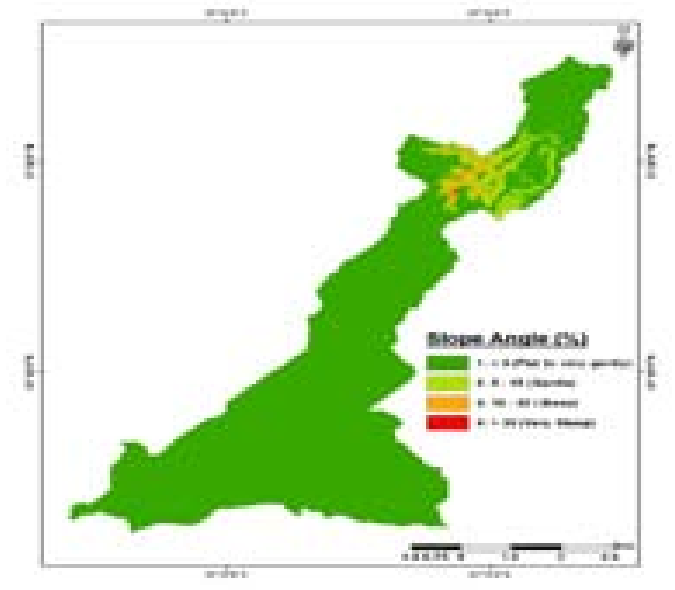

Fig. 8. Slope degrees map of the study area
TABLE 13. Slope classes and its distribution of the study area

\begin{tabular}{|c|c|c|c|}
\hline $\begin{array}{c}\text { Slope } \\
\text { Class }\end{array}$ & Area (ha) & Area (fed) & $\%$ \\
\hline 1 & 8345.6 & 19870.5 & 94.2 \\
\hline 2 & 389.8 & 928.1 & 4.4 \\
\hline 3 & 115.2 & 274.2 & 1.3 \\
\hline 4 & 8.9 & 21.1 & 0.1 \\
\hline Total Area & $\mathbf{8 8 5 9 . 5}$ & $\mathbf{2 1 0 9 4 . 0}$ & $\mathbf{1 0 0 . 0}$ \\
\hline
\end{tabular}

It can be seen that about 8345.6 ha (about $94.2 \%$ of the studied area) have less than $5 \%$ slope angle (class 1 ) and 389.8 hectare (about $4.4 \%$ of the studied area) have $5-15 \%$ slope angle from steep to very steep which is subjected to high erosion rate.

Land cover index

Land cover is one of the most important factors in the soil erosion risk assessment. Soil erosion accelerates due to inappropriate land uses. The vegetative cover and land use conventions of the study site have been detected by visual Interpretation and field work and digitized of LANDSAT-8 and Table 14. show land cover distribution of the studied area as follows:

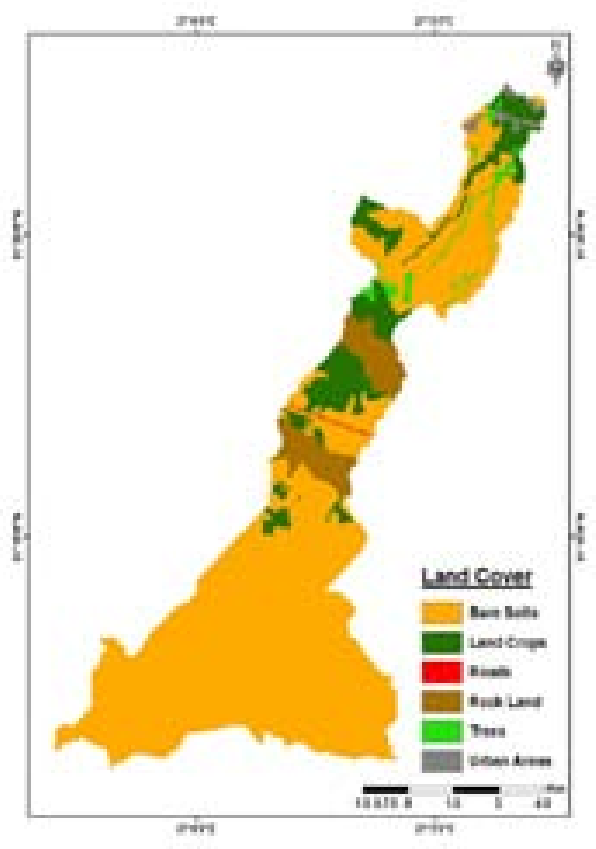

Fig. 9. Land cover map of the study area

Egypt. J. Soil Sci., Vol. 57, No.1 (2017)

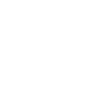


TABLE 14. Land covers distribution of the study area

\begin{tabular}{|c|c|c|c|}
\hline Land Cover Class & Area (ha) & Area (fed) & \% \\
\hline Land Crops & 996.8 & 2373.2 & 11.3 \\
\hline Trees & 154.4 & 367.7 & 1.7 \\
\hline Settlement areas & 81.4 & 193.9 & 0.9 \\
\hline Roads & 12.6 & 30.0 & 0.1 \\
\hline Bare Soils & 7044.2 & 16771.8 & 79.5 \\
\hline Rock Land & 570.1 & 1357.3 & 6.4 \\
\hline Total Area & $\mathbf{8 8 5 9 . 5}$ & $\mathbf{2 1 0 9 4 . 0}$ & $\mathbf{1 0 0 . 0}$ \\
\hline
\end{tabular}

From the previous results most of the study area is bare soils with a distribution of $79.5 \%$ of the study area. Land crops and trees occupy 1151.2 ha., bout $13.0 \%$ of the study area. The settlement area and roads are covered a small areas $(0.9 \%$ and $0.1 \%$, respectively). The settlement areas and road together occupy 94 ha. of the study area $(1.06 \%)$.

Results showed that the areas that classified as non protected areas covered by 8195.4 ha (about $92.5 \%$ of the studied area), whereas, the full protected areas covered 664.1 ha (about 7.5\% of the studied area)

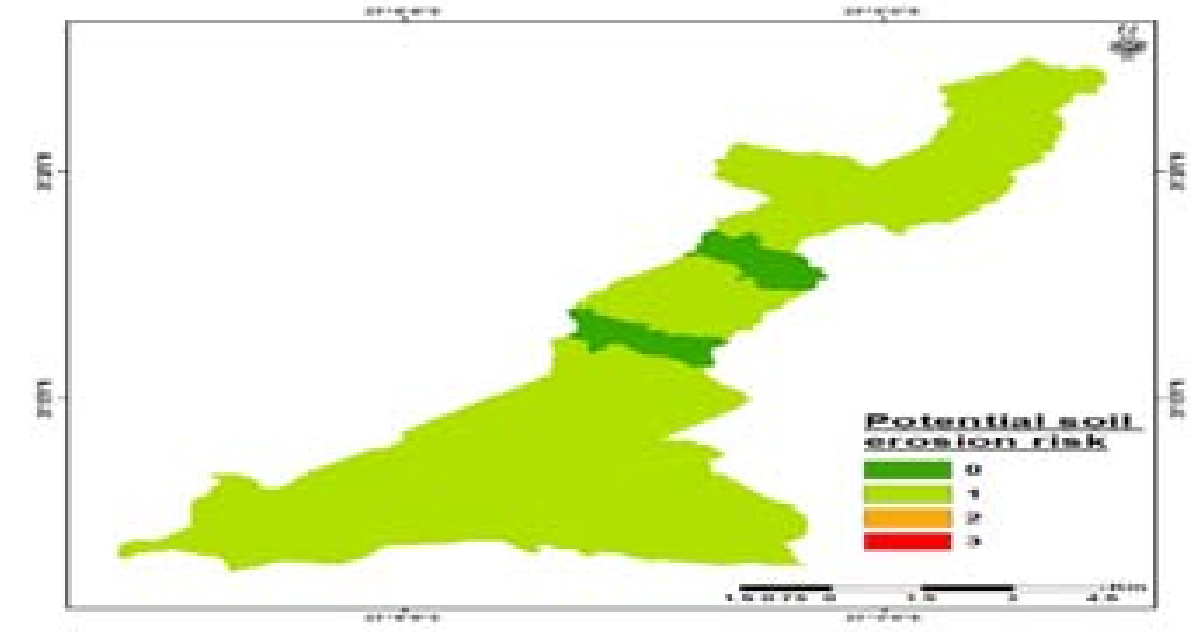

Fig. 10. Potential soil erosion risk of the study area

TABLE 15. Potential soil erosion risk classes of the study area

\begin{tabular}{|c|c|c|c|}
\hline Potential soil erosion risk class & Area (ha) & Area (fed) & \% \\
\hline 0 & 570.1 & 1357.4 & 6.4 \\
\hline 1 & 8279.3 & 19712.5 & 93.5 \\
\hline 2 & 9.9 & 23.6 & 0.1 \\
\hline 3 & 0.2 & 0.4 & 0.0 \\
\hline Total Area & $\mathbf{8 8 5 9 . 5}$ & $\mathbf{2 1 0 9 4 . 0}$ & $\mathbf{1 0 0 . 0}$ \\
\hline
\end{tabular}

Egypt. J. Soil Sci., Vol. 57, No.1 (2017)

Potential soil erosion risk

The potential soil erosion risk (PSER) represents the possible situation of soil erosion risk. It shows the inherent risk of soil erosion on the basis of the physical environmental conditions, potential soil erosion risk PSER, Fig.10 and Table 15 showed that the area exposed to potential erosion risk occupied the largest area found in the map, whereas, the areas with little danger erosion risk occupy a small areas. independently of current land use. The data of

Actual soil erosion risk

Actual soil erosion risk is more related to the current risk of erosion under current vegetation and land use conditions. Results of ASER, Fig. 11 showed that 70442 ha of the studied area are exposed to actual erosion risk and clasified as moderate erosion risk. The area that has ctual erosion risk covers about 1815,3 ha (around $20.49 \%$ of the studied area). The areas exposed ASER are less than the PSER ares. Land use (n) This is ue to the role of land cover in increasing sol

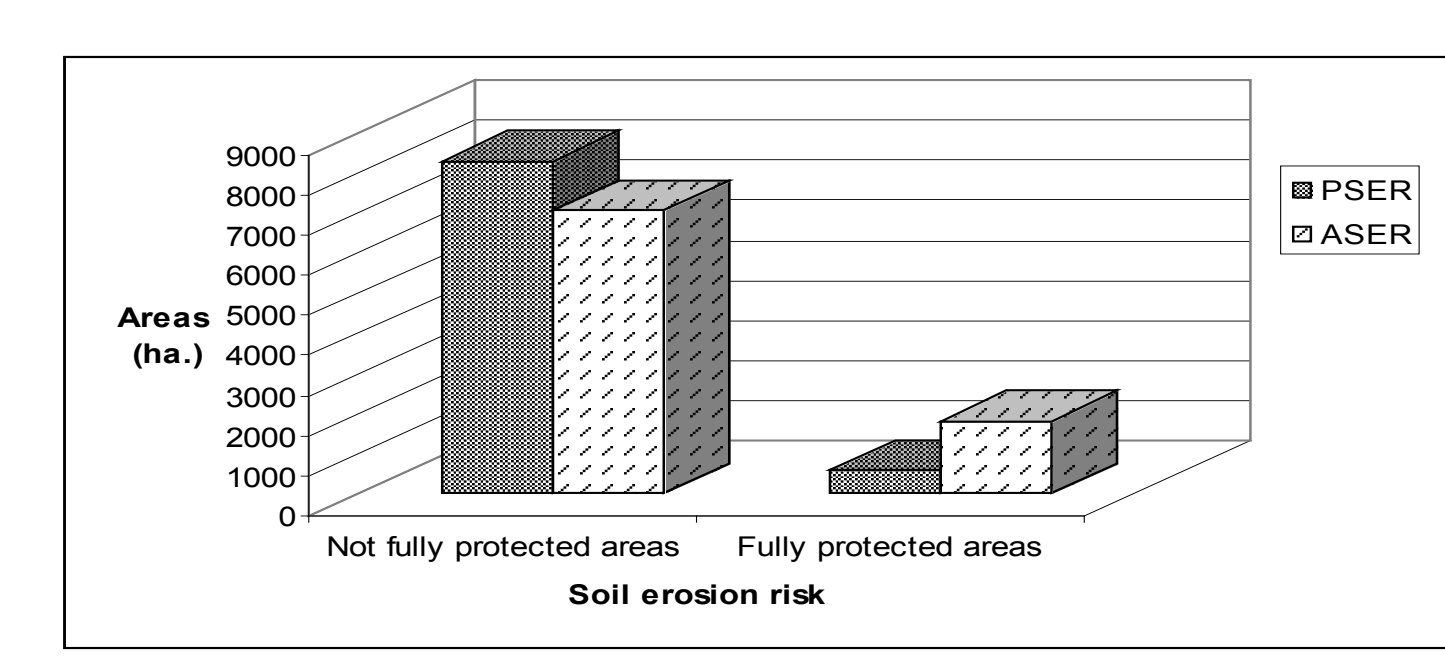

Fig. 11. Potential and actual soil erosion risk of the study area

\section{Conclusions}

1. This study demonstrated that the study are is under low-moderate erosion risk level. Therefore, these areas need good management practices for effective erosion control.

2. It is necessary to use the recent techniques of remote sensing, geographic information system and modeling in detecting and monitoring the qualitative and quantitative soil erosion process and its risk.

3. Following these recent techniques in this application in oller regions differentiated in erms of soil, vegetation, and climatic conditions could help in avoiding land degradation process.

4. It should be having a data concerning sol erosion when it is planning to land use new areas in basin, wadies and valleys as it protection of the studied area. When the land cover was taken into account, soil erosion risk decreased. Soil erosion may be a slow process that continues relatively unnoticed, or it may occur at an alarming ate causing serious loss of top soil. Therefore, is important to predict actual and potential soi erosion risk in order to adopt suitable soil erosion prevention measures. These results also indicated that it is possible and practical to quantitatively assess and predict soil erosion risk at the region cale for efficient planning of conservation programs. facilitate and accelerate the development of strategies and take actions necessary.

\section{$\underline{\text { References }}$}

Ananda, J. and Herath, G. (2003) Soil erosion in developing countries: a socio-economic appraisal. J Environ. Manage. 68,343-353.

Aydin, A. and Tecimen, H.S. (2010). Temporal soil erosion risk evaluation. a CORINE methodology application at Elmalı dam watershed, Istanbul. Environ. Earth Sci. 61:1457-1465

Corbane, C.; Raclot, D.; Jacob, F.; Albergel, J. and Andrieux, P. (2008). Remote sensing of soil surface approach. Catena, 75, 308-318.

CORINE (1992) Soil erosion risk and important land resources in the Southeastern regions of the Egypt. J. Soil Sci., Vol. 57, No.1 (2017) characteristics from a multiscale classification 
European community. EUR 13233, Luxembourg, Belgium, pp 32-48.

Dragut, L. and Eisank, C. (2012). Automated objectbased classification of topography from SRTM data. Geomorphology, 141-142: 21-33.

Eroglu, H.; Cakir, G.; Sivrikaya. F. and Akay, A.E. (2010) Using high resolution images and elevation data in classifying erosion risks of bare soil areas in he Hatila Valley Natural Protected Area, Turkey. Stoch Environ Res Risk Assess 24,699-704.

E.M.A. (2014) Egyptian Meteorological Authority.

Gobin, A.; Govers, G.; Jones, R.; Kirkby, M. and Kosmas, C. (2003). Assessment and reporting on soil erosion. Technical report No. 94, Copenhagen

Husnjak, S.; Simunic, I. and Tursic, I. (2008). Soil erosion risk in Croatia. Cereal Res Commu 36,939-942

Klute, A. (1986). Water retention: Laboratory methods p.635-662. Methods of Soil Analysis, Part 1,2nd ASA and SSSA, Madison. WI, USA.

Liu, B.Y.; Nearing, M.A.; Shi, P.J. and Jia, Z.W. (2001) Slope length effects on soil loss for steep slopes. Soil. Sci. Soc. Am., vol. 64, pp. 1759-1763.

Lu, D.; Li, G.; Valladares, G.S. and Batistella, M. (2004) Mapping soil erosion risk in Rondonia Brazilian Amazonia: using RULSE, remote sensing and GIS. Land Degrad Dev 15,499-512

M.S.A. (1986) Topographic Map Scale 1: 25,000, edition by military survey authority based on sol survey 1970.

Page, A. L., Miller, R.H. and Keeney, D.R. (1982). Methods of Soil Analysis Part 2: Chemical and Microbiological Properties, 2nd ed., Amer. Soc. Agron., Madison, Wisconsin, USA.

Parlak, M.; Dincsoy, Y. and Seyrek, K. (2007). Determination of erosion risk according to CORINE methodology (a case study. Kurtbogaz dam). Int Congress River Basin Manage 1,844-859

Stein, A. (1998) Spatial statistics for soil and the environment, soil survey course, ITC, lecture note, Enschede, The Netherlands.

Egypt. J. Soil Sci, Vol. 57, No.1 (2017)
Wang, G., Gertner, G., Fang, S. and Anderson, AB. (2003) Mapping multiple variables for predicting soil loss by geostatistical methods with TM images and a slope map. Photogramm Eng. Remote. Sens. 69, 889-898.

Wischmeier, W.H. and Smith, D .D (1978). Predicting rainfall erosion losses: a guide to co nservation shington, D C, pp:

Yuksel, A.; Gundogan, R. and Akay, A.E. (2008) Using the remote sensing and GIS technology for
erosion risk mapping of Kartalkaya Dam Watershed in Kahramanmaras, Turkey. Sensors, 8,4851-4865

Zinck, J. A. (1988). Geomorphology and Soils. Interna Publ., ITC., Enschede, The Netherlands.

(Received: 20/12/2015; accepted : 10/1/2016)

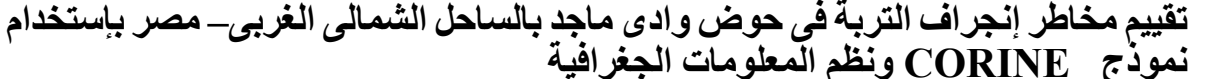

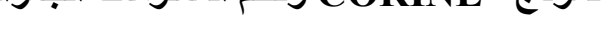

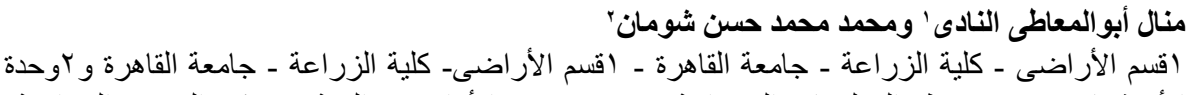

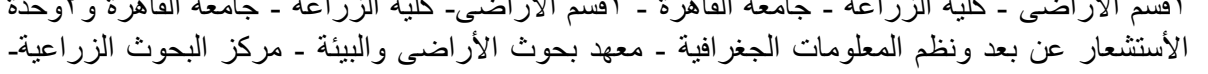

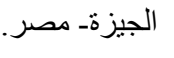

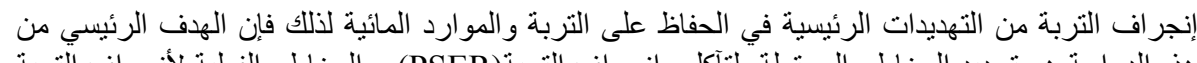

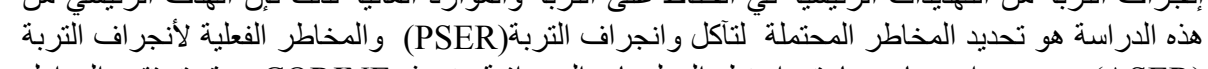

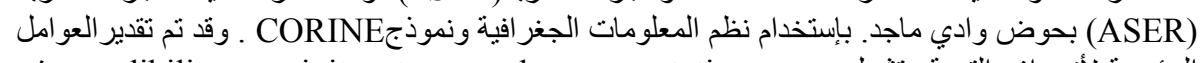

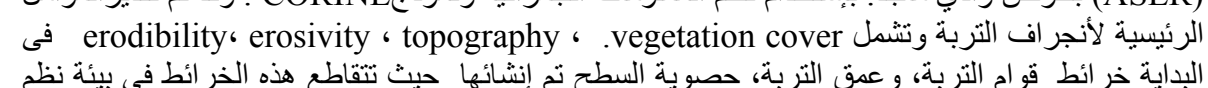

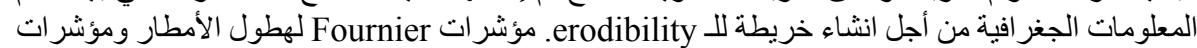

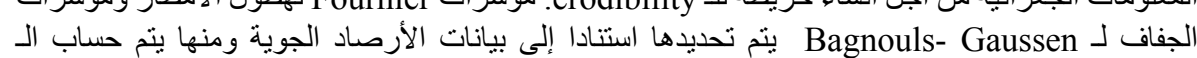

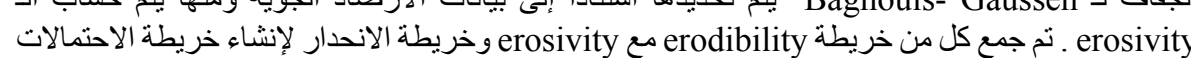

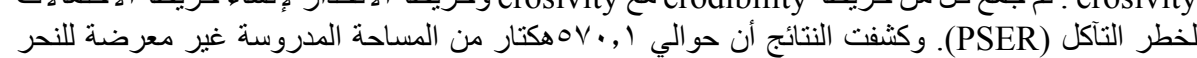

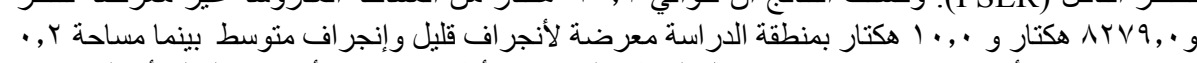

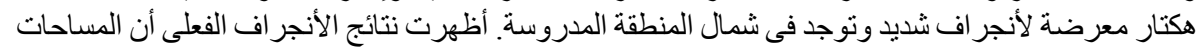

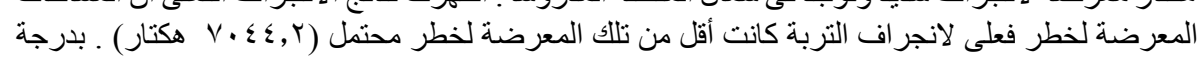

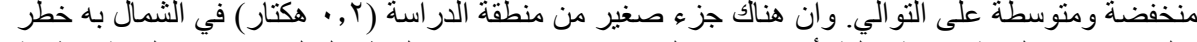

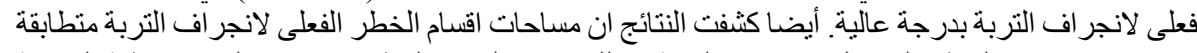

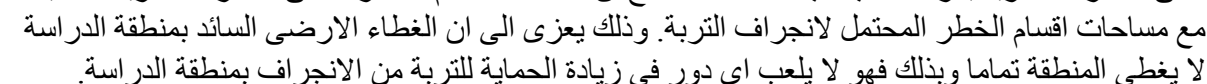

